\title{
The fine structure of the midgut epithelium in Xerobiotus pseudohufelandi (Iharos, 1966) (Tardigrada, Eutardigrada, Macrobiotidae)
}

\author{
Magdalena M. ROST-ROSZKOWSKA, ${ }^{1 *}$ Izabela POPRAWA, ${ }^{1}$ Marta HYRA, ${ }^{1}$ Monika MAREK-SWĘDZIOŁ,${ }^{1}$ \\ Łukasz KACZMAREK ${ }^{2}$
}

${ }^{1}$ University of Silesia, Department of Animal Histology and Embryology, Bankowa 9, 40-007 Katowice, ${ }^{2}$ A. Mickiewicz University, Department of Animal Taxonomy and Ecology, Umultowska 89, 61-614 Poznań, Poland

*Corresponding author: magdalena.rost-roszkowska@us.edu.pl

\begin{abstract}
The aims of our studies were to describe the ultrastructure of the midgut epithelial cells of the eutardigrade Xerobiotus pseudohufelandi and to determine if there are any differences in the ultrastructure of midgut epithelial cells between males and females. The analysis was performed with the use of the light and transmission electron microscopes. In X. pseudohufelandi the midgut epithelium is composed of digestive cells, but in the anterior portion of the midgut a group of cells with different ultrastructure has been observed. Histochemical staining showed the accumulation of reserve material in the cytoplasm of digestive cells. We suggest that some of them fulfil the role of regenerative cells (crescent-like cells, midgut stem cells), whereas others are differentiating cells which form new digestive cells. No differences in the ultrastructure of the midgut epithelium between males and females were distinguished except in the amount of multivesicular bodies.
\end{abstract}

Key words: Tardigrada, midgut epithelium, multivesicular bodies.

\section{INTRODUCTION}

Tardigrades are small invertebrates, which are widespread in terrestrial, freshwater and marine environments (Dewel et al., 1993; Kinchin, 1994; Nelson et al., 2010). Some species are able to survive under various and also extreme environments that are lethal to most organisms (Rebecchi et al., 2009a, 2009b; Nelson et al., 2010). It has been established that encystation and cryptobiosis in tardigrades are adaptive responses to changes in the external environment (Węglarska, 1957; Szymańska, 1995; Wright, 2001; Guidetti et al., 2006, 2011; Rebecchi et al., 2007, 2009b, 2009c; Wełnicz et al., 2011). However, other potential mechanisms which might be involved in the maintenance of homeostasis in invertebrates, such as apoptosis, self-regeneration of tissues and organs, accumulation of spherites, synthesis of methallothioneins or antioxidants (Parthasarathy and Palli, 2007; Park and Takeda, 2008; Hakim et al., 2010; Rost-Roszkowska et al., 2010a, 2010b, 2012; Chajec et al., 2012), have been studied only in some tardigrade species (Rebecchi et al., 2009a; Rizzo et al., 2010; Bonifacio et al., 2012). In many invertebrates the regenerative properties of the midgut epithelium are also considered as adaptive mechanisms for coping with external stress factors (Wilczek, 2005; Tettamanti et al., 2007; Park and Takeda, 2008; Malagoli et al., 2010; Rost-Roszkowska et al., 2011b; Franzetti et al., 2012).

Given that the tardigrade Xerobiotus pseudohufelandi (Iharos, 1966) inhabits dry terrestrial environments and is able to survive long periods of drought in an anhydrobiotic state (own observations), it is a suitable organism to study mechanisms for coping with external stress, including the regenerative properties of the midgut epithelium. The aims of our studies were: i) to describe the ultrastructure of the midgut epithelial cells of $X$. pseudohufelandi; ii) to determine if there are any differences in the ultrastructure of midgut epithelial cells between males and females; iii) to distinguish stem cells among the midgut cells.

\section{METHODS}

Xerobiotus pseudohufelandi (Eutardigrada, Macrobiotidae) was extracted using standard methods (Dastych, 1980) from sandy soil samples collected from a pine forest near the Collegium Physicum, the Morasko University Campus, Poznań, Wielkopolska Voivodeship, Poland $\left(52^{\circ} 28^{\prime} 04.70^{\prime \prime} \mathrm{N} ; 16^{\circ} 55^{\prime} 45.47^{\prime \prime} \mathrm{E}, 92 \mathrm{~m}\right.$ asl).

\section{Light and transmission electron microscope analysis}

We examined midguts of 42 adult specimens (males and females). Specimens were fixed with $2.5 \%$ glutaraldehyde in $0.1 \mathrm{M}$ sodium phosphate buffer ( $\mathrm{pH} 7.4$ ), for $2 \mathrm{~h}$ at $4{ }^{\circ} \mathrm{C}$. The material was then post-fixed in $2 \%$ osmium tetroxide in a $0.1 \mathrm{M}$ phosphate buffer for $1.5 \mathrm{~h}$ at $4{ }^{\circ} \mathrm{C}$, dehydrated in increasing concentrations of ethanol (50, 70, 90,95 and $100 \%$, each for $15 \mathrm{~min}$ ), transferred to acetone for $15 \mathrm{~min}$, and finally embedded in epoxy resin (Epoxy Embedding Medium Kit; Sigma Aldrich Inc., St Louis, MO, USA). Semi- (800 nm thick) and ultra-thin $(70 \mathrm{~nm})$ sections were cut on a Leica Ultracut UCT25 ultramicro- 
tome (Leica, Wetzlar, Germany). Semi-thin sections were stained with $1 \%$ methylene blue in $0.5 \%$ borax and observed with an Olympus BX60 light microscope (Olympus Corporation, Tokyo, Japan). Ultra-thin sections were stained with uranyl acetate and lead citrate and examined with a Hitachi H500 transmission electron microscope at 75 kV (Hitachi Ltd., Tokyo, Japan).

\section{Histochemistry}

To detect lipids, semi-thin sections were stained with Sudan Black B at room temperature for $20 \mathrm{~min}$.

Glycogen and polysaccharides were detected using the Periodic acid-Schiff (PAS) method. To remove osmium, semi-thin sections were treated with $2 \%$ solution of periodic acid $\left(\mathrm{HIO}_{4}\right)$ for $10 \mathrm{~min}$ at room temperature and then they were stained with Schiff's reagent for $24 \mathrm{~h}$ at $37^{\circ} \mathrm{C}$.

To detect protein, first semi-thin sections were treated with a $2 \%$ solution of periodic acid for $10 \mathrm{~min}$ at room temperature to remove osmium, then they were stained with bromophenol blue (BPB) for $24 \mathrm{~h}$ at $37^{\circ} \mathrm{C}$.

\section{RESULTS}

No differences between females and males of $X$. pseudohufelandi were observed in the ultrastructure of the midgut epithelium with the exception in the amount of multivesicular bodies (MVBs). Therefore, the results presented here refer to both females and males.

The midgut epithelium of $X$. pseudohufelandi (Fig. 1a and $1 \mathrm{~b}$ ) is formed by flat or cubic digestive cells. Their nuclei are located in the central region of the cytoplasm (Fig. 1c). In some cases the apical cell region forms a large evagination into the midgut lumen, making the epithelial surface folded. In these digestive cells the nucleus is present in this evagination of the apical cytoplasm (Figs. 1c and 3d).

The cytoplasm of the digestive cells does not show any regionalization in organelle distribution, which is most likely caused by the flat or cubic shape of cells. The basal cell membrane invaginates slightly into the cytoplasm forming membranous folds. Numerous cisterns of the rough endoplasmic reticulum (RER) are present (Fig. 1d) in their neighbourhood. Near the apical membrane, which forms microvilli that enter the midgut lumen, numerous small, coated vesicles are visible (Fig. 1b, 1d, 1e). They are formed due to endocytosis, when coated pits appear (Fig. 1e and 1f). Between the midgut and foregut or hindgut the number of microvilli is low (Fig. 1g). The entire cytoplasm of the digestive cell is rich in cisterns of RER and smooth endoplasmic reticulum (SER), mitochondria and free ribosomes (Fig. 2a). Golgi complexes have not been observed in the cytoplasm of digestive cells.

In many individuals several electron-lucent and electron-dense spheres of reserve material occur in the cytoplasm of digestive cells (Fig. 2b). Histochemical analyses showed that these are mainly lipids, whereas proteins and saccharides are rare (Fig. 3a, 3b, 3c). No differences in the amount of reserve material in the cytoplasm of digestive cells are found between females and males. In some specimens, which have the reserve material, large MVBs also appear (Fig. 2d and 2f). Intensive endocytosis (Fig. 2d and 2e), numerous small coated vesicles that originate from endocytosis (Fig. 2c and 2e), and cisterns of RER are present in the neighbourhood of MVBs. The process of vesicle fusion with MVBs has been recorded (Fig. $2 \mathrm{~g}$ and 2h). Many more MVBs are present in the midgut epithelium of females than that of males (Fig. 2d, 2f, 2j).

Smooth septate junctions and septate junctions are distinguished between adjacent digestive cells (Fig. 4a). A group of cells with cytoplasm that differs from that of the digestive cells is present between the foregut and the midgut (Fig. 4b, 4c, 4d). These cells (herein called crescent-like cells) form a kind of epithelial ring that surrounds the epithelium of the foregut (Fig. $4 \mathrm{~b}$ ). The cytoplasm of cells in the epithelial ring contains many mitochondria and some cisterns of RER, but it is completely devoid of the reserve material (Fig. 4c). Between the crescent-like cells and the digestive cells of the midgut are young differentiating digestive cells (Fig. 4c and 4d). Together with numerous cisterns of RER and mitochondria, small amounts of the reserve material are also visible in their cytoplasm (Fig. 4c).

No mitotic divisions in the midgut epithelium or in the crescent-like cells have been described.

\section{DISCUSSION}

Up to now two kinds of cells have been described in the midgut epithelium of tardigrades: digestive cells that form the epithelium and crescent-like cells situated between the foregut and the midgut (Bertolani, 1970; Dewel and Clark, 1973; Greven, 1976; Kristensen, 1976; Pirch and Greven, 1994; Ząbczyk, 2000; Avdonina et al., 2007; RostRoszkowska and Poprawa, 2008; Rost-Roszkowska et al., 2011a).

Fig. $4 \mathrm{~d}$ shows a schematic representation of the different kinds of cells observed in the midgut of $X$. pseudohufelandi. From the beginning of the midgut these cells are: midgut regenerative cells, midgut differentiating cells, and finally digestive cells. Therefore at the anterior end of the midgut epithelium of $X$. pseudohufelandi a group of cells forms a structure that we refer to as the epithelial ring. Cells of the epithelial ring correspond to crescent-like cells (midgut regenerative cells) described in some tardigrade species (Bertolani, 1970; Dewel and Clark, 1973; Greven, 1976; Ząbczyk, 2000; Rost-Roszkowska et al., 2011a). However, we did not observe their proliferation, a characteristic feature of midgut regenerative cells of invertebrates (Hakim et al., 2010; Nardi et al., 2010). Still, it is probable that these cells may divide at specific periods of the life cycle (e.g. during moulting) as has been described or sug- 

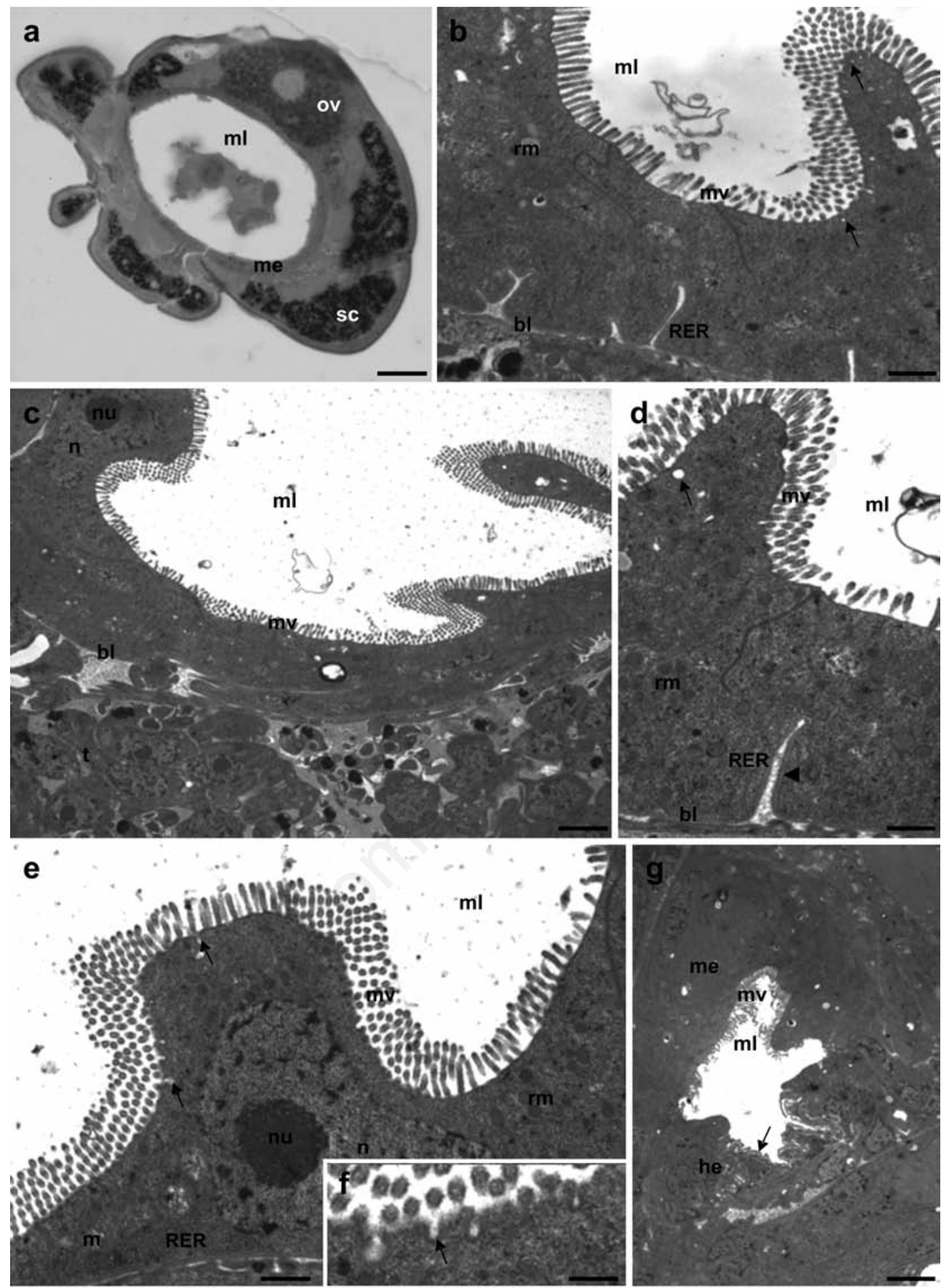

Fig. 1. Midgut epithelium of Xerobiotus pseudohufelandi. a, image obtained with light microscopy (LM); b-g, image obtained with transmission electron microscopy (TEM). a) Cross section through the body of a tardigrade; b) a fragment of the midgut epithelium showing cisterns of rough endoplasmic reticulum, reserve material and small vesicles (arrows); c) digestive cells of the midgut epithelium with distinct basal lamina and testis; d) basal membrane of digestive cells with membranous folds (arrowhead); e) apical membrane of digestive cells showing microvilli (mv) and endocytosis (arrow); f) higher magnification of the Fig. 1e showing endocytosis (arrow); g) microvilli between midgut (me) and hindgut (he); arrow indicates the cuticle of hindgut. bl=basal lamina; $\mathrm{m}=$ mitochondria; me=midgut epithelium; $\mathrm{ml}=$ midgut lumen; $\mathrm{mv}=$ microvilli; $\mathrm{n}=$ nucleus; $\mathrm{nu}=$ nucleolus; $\mathrm{o}=$ ovary; $\mathrm{RER}=$ rough endoplasmic reticulum; $\mathrm{rm}=$ reserve material; $\mathrm{sc}=\mathrm{storage}$ cells; $\mathrm{t}=$ testis. Scale bars of a) $=8.2 \mu \mathrm{m} ; \mathrm{b})=0.7 \mu \mathrm{m} ; \mathrm{c})=1.7 \mu \mathrm{m} ; \mathrm{d}, \mathrm{e})=$ bar $=0.6 \mu \mathrm{m} ; \mathrm{f})=0.2 \mu \mathrm{m} ; \mathrm{g})=2.3 \mu \mathrm{m}$. 

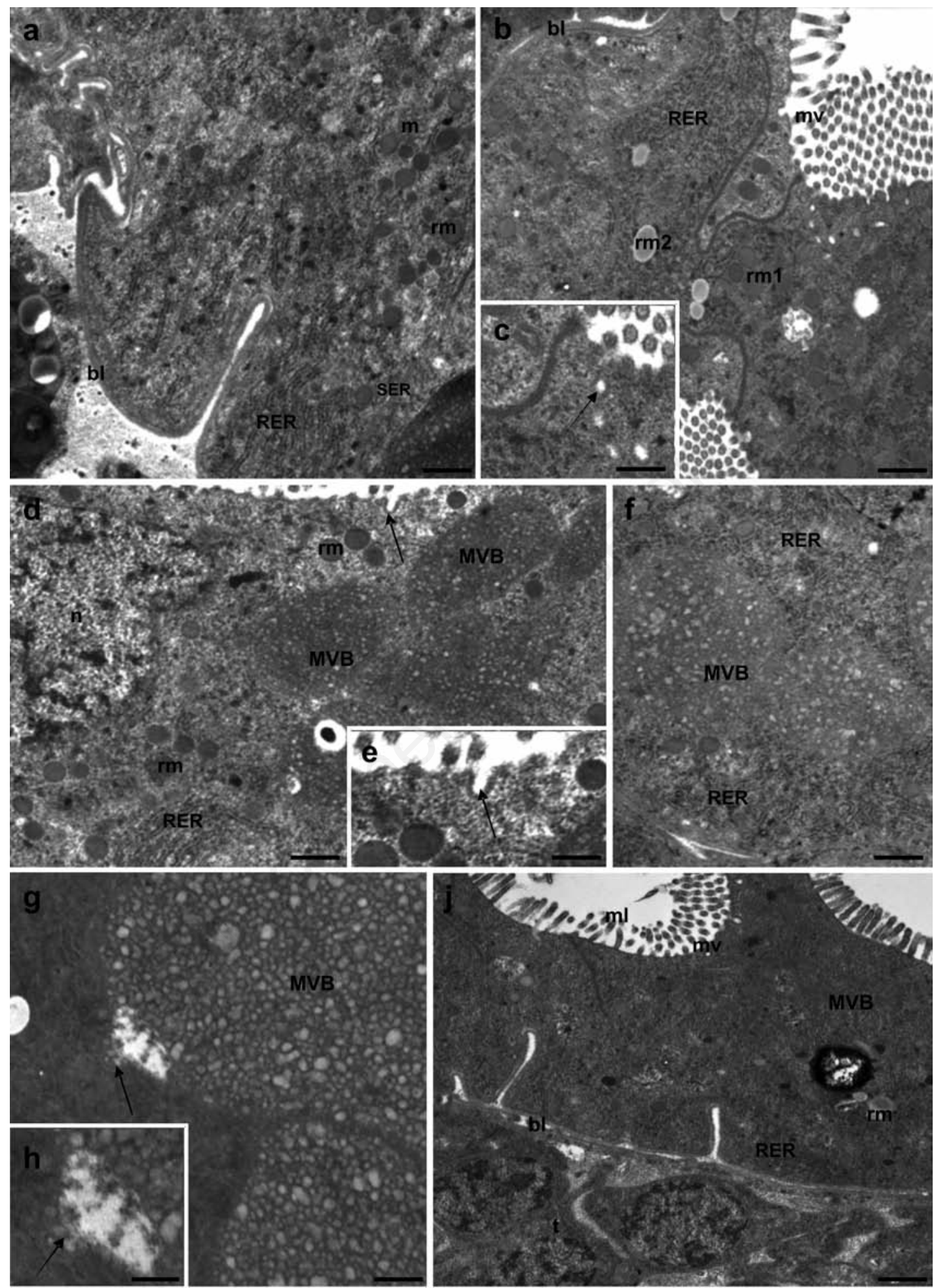

Fig. 2. Digestive cells of Xerobiotus pseudohufelandi. a-j, image obtained with transmission electron microscopy (TEM). a) Basal part of the cytoplasm in a digestive cell; b) cytoplasm of digestive cells; c) higher magnification of the Fig. $2 b$ showing endocytotic vesicle (arrow); d) endocytosis (arrow) in the digestive cell of a female; e) higher magnification of the Fig. 2d showing endocytosis (arrow); f) cisterns of rough endoplasmic reticulum (RER) near multivesicular bodies (MVB) in a female; g) fusion of coated vesicle (arrow) with MVB; h) higher magnification of Fig. $2 \mathrm{~g}$ showing coated vesicle (arrow); j) MVB in the midgut epithelial cells of a male. bl=basal lamina; $\mathrm{m}=$ mitochondria; $\mathrm{ml}=$ midgut lumen; $\mathrm{mv}=$ microvilli; $\mathrm{n}=$ nucleus; $\mathrm{rm}, \mathrm{rm} 1$ and $\mathrm{rm} 2=$ reserve material; $\mathrm{SER}=$ smooth endoplasmic reticulum; $\mathrm{t}=$ testis. Scale bars of $\mathrm{a}, \mathrm{b})=0.5 \mu \mathrm{m} ; \mathrm{c})=0.2 \mu \mathrm{m} ; \mathrm{d})=0.5 \mu \mathrm{m} ; \mathrm{e})=0.3 \mu \mathrm{m} ; \mathrm{f})=0.5 \mu \mathrm{m} ; \mathrm{g})=0.2 \mu \mathrm{m} ; \mathrm{h})=0.1 \mu \mathrm{m} ; \mathrm{j})=0.6 \mu \mathrm{m}$. 
gested for many arthropods (Rost-Roszkowska et al., 2007; Hakim et al., 2010; Nardi et al., 2010; Chajec et al., 2012). Finally, several cells forming the layer of the new/young digestive cells have been observed between crescent-like cells and digestive cells. Because their cytoplasm also possesses small amounts of the reserve material, together with mitochondria and cisterns of RER, we conclude that these cells are differentiating midgut regenerative cells (i.e. midgut progenitor cells). Midgut progenitor cells that differentiate into all types of the midgut epithelial cells have been described mainly for arthropods. They are described as cells which show the features of both midgut stem cells and digestive cells (Martins et al., 2005; Cruz et al., 2011; Chajec et al., 2012).

The amount of reserve material (e.g. lipids, proteins, saccharides) in the tardigrade midgut cells increases to enable the survival of the animal in case of, for example, starvation or any other external stress factor (Greven, 1976; Pirch and Greven, 1994; Rost-Roszkowska and Poprawa, 2008). In Isohypsibius granulifer granulifer Thulin, 1928 (Eutardigrada) numerous structures with reserve material accumulate gradually in the cytoplasm of the midgut digestive cells as oogenesis occurs (RostRoszkowska et al., 2011a). The presence of reserve material in the cytoplasm of the digestive cells has also been described in the eutardigrade Dactylobiotus dispar (Murray, 1907) (Ząbczyk, 2000; Rost-Roszkowska and Poprawa, 2008). In case of $X$. pseudohufelandi differences in the amount of reserve material were not observed between midgut cells of males and females.

Multivesicular bodies are round or oval organelles which possess numerous internal spherical or ellipsoidal vesicles enclosed within a single outer membrane (von Bartheld and Altick, 2011). These organelles may be formed by small vesicles that originate from Golgi complexes or from endocytosis (Martin and Spicer, 1973; Piper and Katzmann, 2007; Büning et al., 2008). In the midgut digestive cells of $X$. pseudohufelandi we observed the fusion of a coated vesicle with a multivesicular body, which might suggest that endocytosis participates in MVB formation. Also, no Golgi complexes were detected in the cytoplasm of digestive cells, which cannot participate in MVB formation, contrary to what is known in other taxa (Martin and Spicer, 1973; Büning et al., 2008). The role of MVBs can be multiple; they may participate in enzyme accumulation (Martin and Spicer, 1973), degradation of membrane proteins (Piper and Katzmann, 2007), growth factor receptor down-regulation (Futter et al., 1996), developmental signalling (Lai et al., 2001), and finally in protein sorting, recycling, transport and release (von Bartheld and Altick, 2011). Because MVBs in X. pseudohufelandi probably are formed with the participation of coated vesicles that originate from endocytosis, we may suppose that these structures take part in the accumulation of substances (e.g. water) that enter the midgut lumen with the food. Further studies are necessary to understand the nature of MVBs and if their presence is widespread among terrestrial tardigrade species.

\section{CONCLUSIONS}

Our study shows that: i) the midgut epithelium of $X$. pseudohufelandi is composed mostly of digestive cells, but

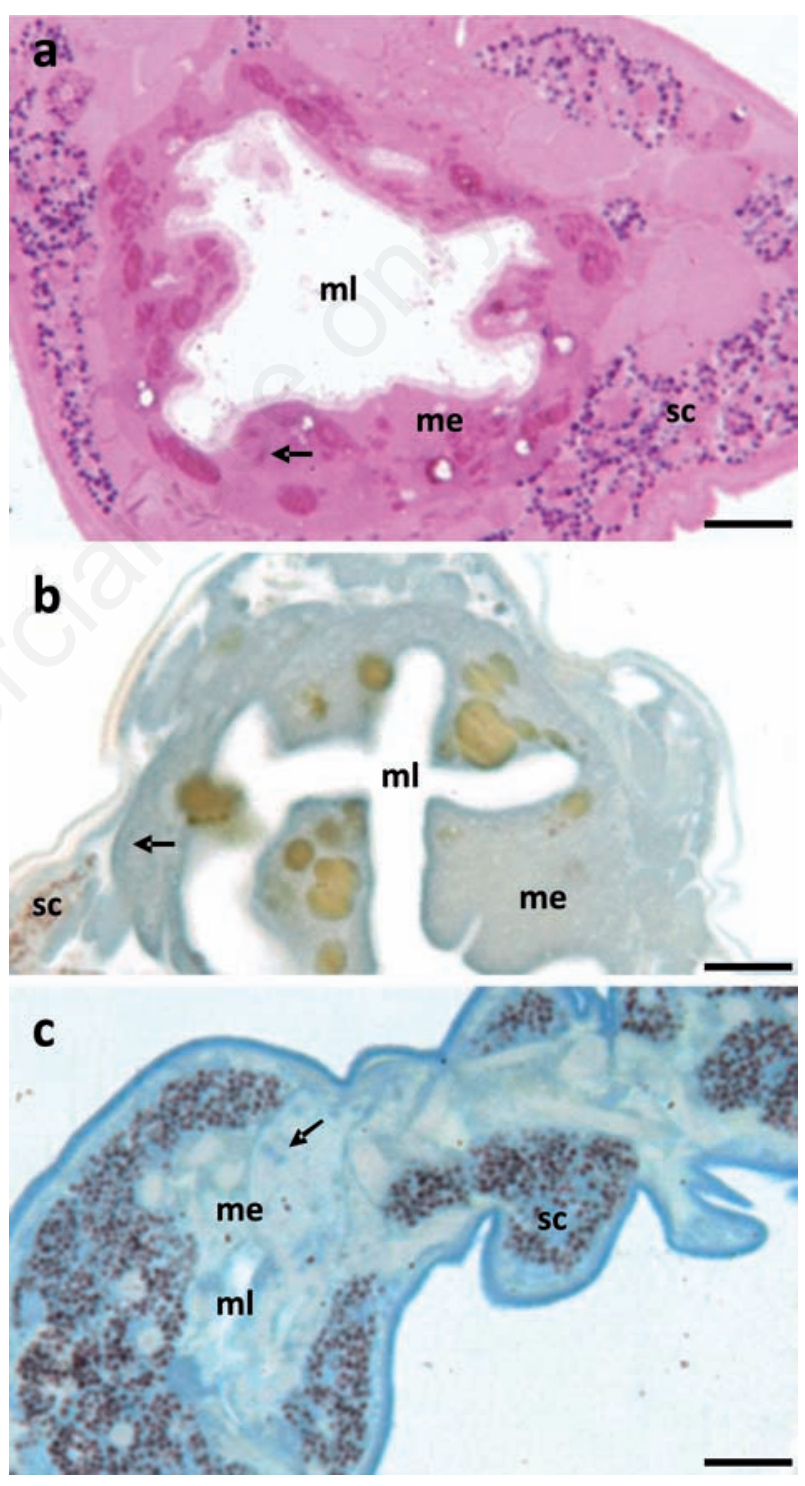

Fig. 3. Histochemical staining of Xerobiotus pseudohufelandi. a-c, image obtained with light microscopy (LM). a) Cross section through the body of a tardigrade. Arrow indicates Periodic acid-Schiff (PAS)-positive granules; b) cross section through the body of a tardigrade. Arrow indicates Sudan-positive granules; c) longitudinal section through the body of a tardigrade. Arrow indicates bromophenol blue (BPB)-positive granules. $\mathrm{me}=$ midgut epithelium; $\mathrm{ml}=$ midgut lumen; $\mathrm{sc}=$ storage cells. Scale bars of a) $=4.5 \mu \mathrm{m} ; \mathrm{b})=3.1 \mu \mathrm{m} ; \mathrm{c})=5.1 \mu \mathrm{m}$. 

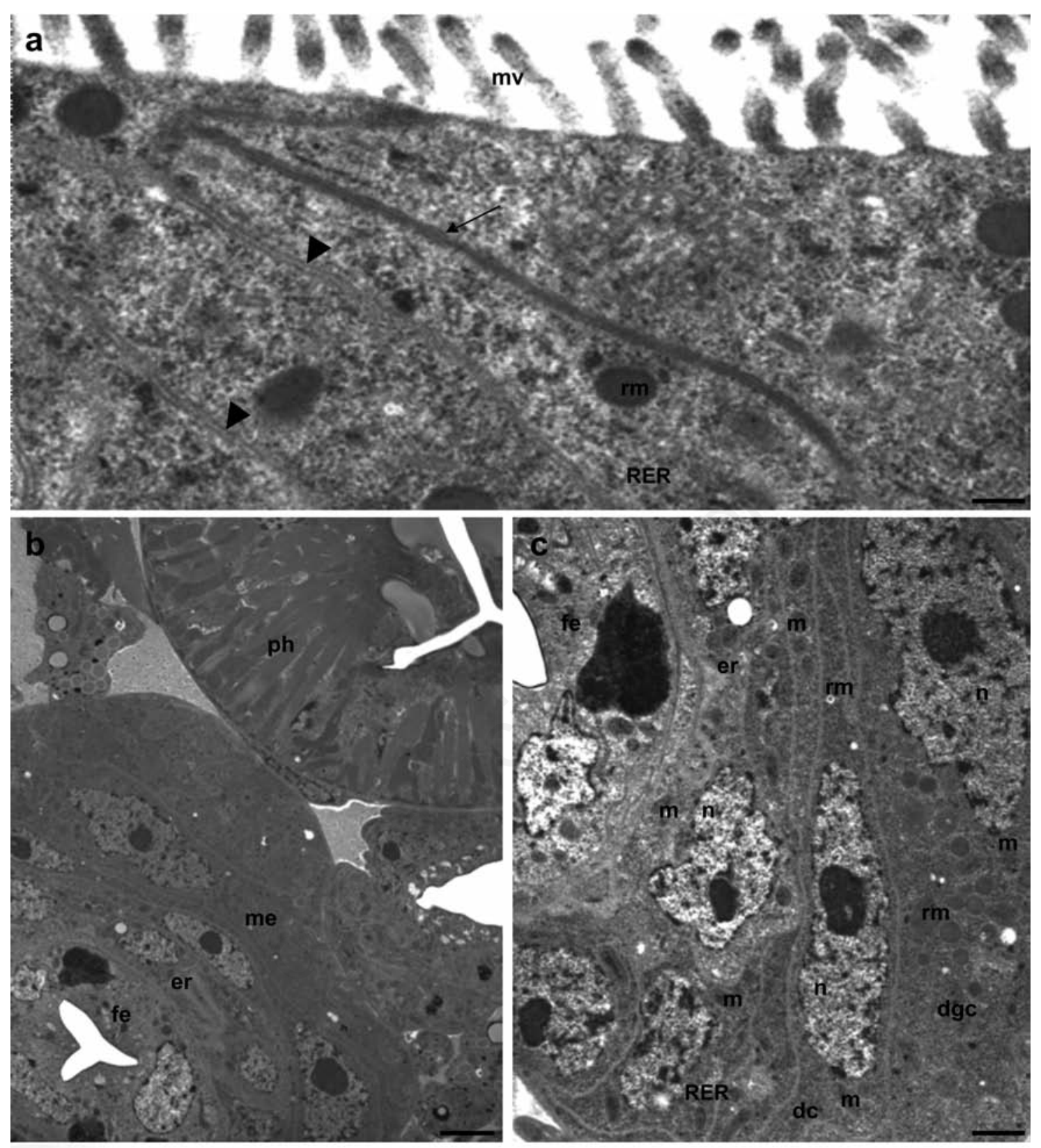

d

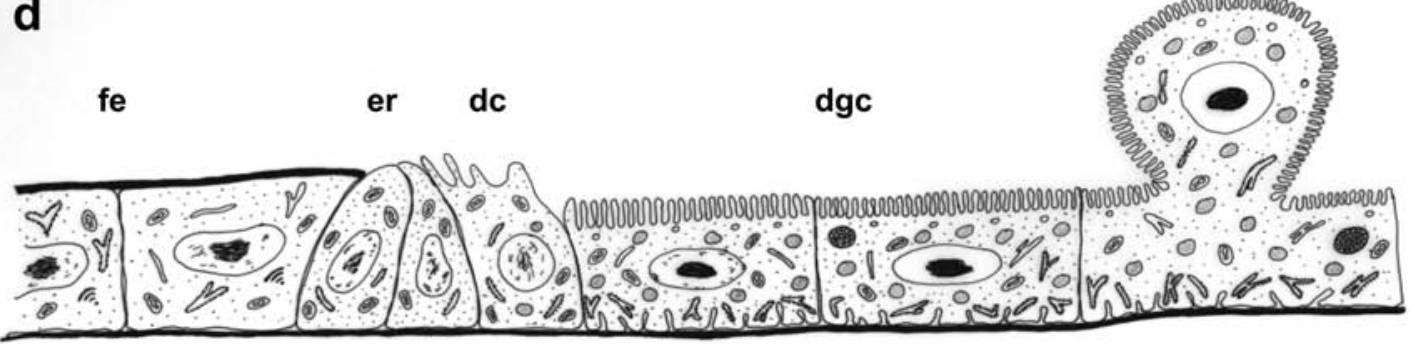

Fig. 4. Digestive system of Xerobiotus pseudohufelandi. a-c, image obtained with transmission electron microscopy (TEM). a) Digestive cells connected with smooth septate junction (arrow) and septate junction (arrowhead); b) epithelial ring between foregut (fe) and midgut (me); c) young differentiating digestive cell between epithelial ring (er) and digestive cell; d) a diagrammatic representation of the midgut epithelium. $\mathrm{dc}=$ young differentiating digestive cell; $\mathrm{dgc}=$ digestive cell; er=epithelial ring; $\mathrm{m}=\mathrm{mitochondria}$; me=midgut epithelium; $\mathrm{mv}=$ microvilli; $\mathrm{n}=$ nucleus; $\mathrm{ph}=$ pharynx; $\mathrm{RER}=$ rough endoplasmic reticulum; $\mathrm{rm}=$ reserve material. Scale bars of a) $=0.2$ $\mu \mathrm{m} ; \mathrm{b})=2.0 \mu \mathrm{m} ; \mathrm{c})=0.8 \mu \mathrm{m}$. 
crescent-like cells are also present; ii) no differences in the ultrastructure of the digestive and crescent-like cells have been observed between males and females with the exception of the amount of multivesicular bodies; iii) a large amount of multivesicular bodies occurs in female midgut digestive cells; iv) crescent-like cells placed between the foregut and midgut probably play a role as midgut stem cells, and v) they differentiate into digestive cells.

\section{ACKNOWLEDGMENTS}

We would like to express our gratitude to Dr. Łukasz Michalczyk (Jagiellonian University, Poland) for valuable remarks on the manuscript.

\section{REFERENCES}

Avdonina AM, Biserova NM, Bertolani R, Rebecchi L, 2007. Ultrastructure of the digestive system of Ramazzottius tribulosus and Macrobiotus richtersi (Eutardigrada) in relation with diet. J. Limnol. 66(Suppl.1):5-11.

Bertolani R, 1970. [Mitosi somatiche e costanza cellulare numerica nei tardigradi]. [Article in Italian]. Atti Accad. Naz. Lincei Rend. Ser. 8 $8^{\text {a }}$ 48:739-742.

Bonifacio A, Guidetti R, Altiero T, Sergo V, Rebecchi L, 2012. Nature, source and function of pigments in tardigrades: in vivo Raman imaging of carotenoids in Echiniscus blumi. PLoS ONE 7:e50162.

Büning J, von Smolinski D, Tafazzoli K, Zimmer KP, Strobel S, Apostolaki M, Kollias G, Heath JK, Ludwig D, Gebert A, 2008. Multivesicular bodies in intestinal epithelial cells: responsible for MHC class II-restricted antigen processing and origin of exosomes. Immunology 125:510-521.

Chajec Ł, Rost-Roszkowska MM, Vilimova J, Sosinka A, 2012. Ultrastructure and regeneration of midgut epithelial cells in Lithobius forficatus (Chilopoda, Lithobiidae). Invertebr. Biol. 131:119-132.

Cruz LC, Araújo VA, Dolder H, Araújo APA, Serrão J, Neves CA, 2011. Morphometry of the midgut of Melipona quadrifasciata anthidioides (Lepeletier) (Hymenoptera: Apidae) during metamorphosis. Neotrop. Entomol. 40:677-681.

Dastych H, 1980. [Niesporczaki (Tardigrada) Tatrzańskiego Parku Narodowego]. [Article in Polish]. Monografie Fauny Polski PWN 9:1-232.

Dewel RA, Clark WH Jr, 1973. Studies on the tardigrades. III. Fine structure of the esophagus of Milnesium tardigradum Doyère. Tissue Cell 5:161-169.

Dewel RA, Nelson DR, Dewel WC, 1993. Tardigrada, p. 143183. In: F.E. Harrison and M.E. Rice (eds.), Microscopic Anatomy of Invertebrates. 12. Onychophora, Chilopoda and Lesser Protostomata. Wiley-Liss.

Franzetti E, Huang Z-J, Shi Y-X, Xie K, Deng X-J, Li J-P, Li QR, Yang W-Y, Zeng W-N, Casartelli M, Deng H-M, Cappellozza S, Grimaldi A, Xia Q, Feng Q, Cao Y, Tettamanti G, 2012. Autophagy precedes apoptosis during the remodelling of silkworm larval midgut. Apoptosis 17:305-324.

Futter CE, Pearse A, Hewlett LJ, Hopkins CR, 1996. Multivesicular endosomes containing internalized EGF-EGF receptor complexes mature and then fuse directly with lysosomes. J. Cell Biol. 132:1011-1023.
Greven H, 1976. Some ultrastructural observations on the midgut epithelium of Isohypsibius augusti (Murray, 1907) (Eutardigrada). Cell Tissue Res. 166:339-351.

Guidetti R, Altiero T, Rebecchi L, 2011. On dormancy strategies in tardigrades. J. Insect Physiol. 57:567-576.

Guidetti R, Boschini D, Rebecchi L, Bertolani R, 2006. Encystment processes and the "matrioshka-like stage" in a mossdwelling and in a limnic species of eutardigrades (Tardigrada). Hydrobiologia 558: 9-21.

Hakim RS, Baldwin K, Smagghe G, 2010. Regulation of midgut growth, development and metamorphosis. Annu. Rev. Entomol. 55:593-608.

Kinchin IM, 1994. The biology of tardigrades. Portland, London: $186 \mathrm{pp}$.

Kristensen RM, 1976. On the fine structure of Batillipes noerrevangi Kristensen 1976. I. Tegument and moulting cycle. Zool. Anz. 197:129-150.

Lai EC, Deblandre GA, Kintner C, Rubin GM, 2001. Drosophila neuralized is a ubiquitin ligase that promotes the internalization and degradation of delta. Dev. Cell 1:783-794.

Malagoli D, Abdalla FC, Cao Y, Feng Q, Fujisaki K, Gregorc A, Matsuo T, Nezis IP, Papassideri IS, Sass M, Silva-Zacarin ECM, Tettamanti G, Umemiya-Shirafuji R, 2010. Autophagy and its physiological relevance in arthropods current knowledge and perspectives. Autophagy 6:575-588.

Martin BJ, Spicer SS, 1973. Multivesicular bodies and related structures of the syncytiotrophoblast of human term placenta. Anat. Rec. 175:15-35.

Martins GF, Neves CA, Campos LO, Serrão JE, 2005. The regenerative cells during the metamorphosis in the midgut of bees. Micron 37:161-168.

Nardi JB, Bee ChM, Miller LA, 2010. Stem cells of the beetle midgut epithelium. J. Insect Physiol. 56:296-303.

Nelson DR, Guidetti R, Rebecchi L, 2010. Tardigrada, p. 455484. In: J.H. Thorp and A.P. Covich (eds.), Ecology and classification of North American freshwater invertebrates. 14. Third Edition. Academic Press.

Park MS, Takeda M, 2008. Starvation suppresses cell proliferation that rebounds after refeeding in the midgut of the American cockroach, Periplaneta americana. J. Insect Physiol. 54:386-392.

Parthasarathy R, Palli SR, 2007. Developmental and hormonal regulation of midgut remodeling in a lepidopteran insect, Heliothis virescens. Mech. Dev. 124:23-34.

Piper RC, Katzmann DJ, 2007. Biogenesis and function of multivesicular bodies. Ann. Rev. Cell Dev. Biol. 23:519-547.

Pirch J, Greven H, 1994. Fine structure of the midgut and the hindgut in Echiniscus testudo Doyère (Heterotardigrada). Zool. Anz. 232:161-175.

Rebecchi L, Altiero T, Guidetti R, 2007. Anhydrobiosis: the extreme limit of desiccation tolerance. Invertebr. Surv. J. 4:6581.

Rebecchi L, Altiero T, Guidetti R, Cesari M, Bertolani R, Negroni M, Rizzo AM, 2009a. Tardigrade resistance to space effects: first results of experiments on the LIFE-TARSE mission on FOTON-M3 (September 2007). Astrobiology 9:581-591.

Rebecchi L, Boschini D, Cesari M, Lencioni V, Bertolani R, Guidetti R, 2009b. Stress response of a boreo-alpine species of tardigrade, Borealibius zetlandicus (Eutardigrada, Hypsibiidae). J. Limnol. 68:64-70. 
Rebecchi L, Cesari M, Altiero T, Frigieri A, Guidetti R, 2009c. Survival and DNA degradation in anhydrobiotic tardigrades. J. Exp. Biol. 212:4033-4039.

Rizzo AM, Negroni M, Altiero T, Montorfano G, Corsetto P, Berselli P, Berra B, Guidetti R, Rebecchi L, 2010. Antioxidant defences in hydrated and desiccated states of the tardigrade Paramacrobiotus richtersi. Comp. Biochem. Physiol. Part B 156:115-121.

Rost-Roszkowska MM, Poprawa I, 2008. Ultrastructure of the midgut epithelium in Dactylobiotus dispar (Tardigrada: Eutardigrada) during encystation. Zool. Pol. 53:19-25.

Rost-Roszkowska M M, Poprawa I, Kaczmarek Ł, 2011b. Autophagy as the cell survival in response to a microsporidian infection of the midgut epithelium of Isohypsibius granulifer granulifer (Eutardigrada: Hypsibiidae). Acta Zool.

Rost-Roszkowska MM, Poprawa I, Świątek P, 2007. Ultrastructural changes in the midgut epithelium of the first larva of Allacma fusca (Insecta, Collembola, Symphypleona). Invertebr. Biol. 126:366-372.

Rost-Roszkowska M M, Poprawa I, Wójtowicz M and Kaczmarek $€$, 2011a. Ultrastructural changes of the midgut epithelium in Isohypsibius granulifer granulifer Thulin, 1928 (Tardigrada: Eutardigrada) during oogenesis. Protoplasma 248:405-414.

Rost-Roszkowska MM, Vilimova J, Chajec $Ł, 2010$ a. Fine structure of the midgut epithelium of Nicoletia phytophila Gervais, 1844 (Zygentoma: Nicoletiidae: Nicoletiinae) with the special emphasis on its degeneration. Folia Biol. Cracov 58:217-227.

Rost-Roszkowska M, Vilimova J, Jansta P, 2010b. Fine structure of the midgut epithelium in two Archaeognatha, Lepis- machilis notata and Machilis hrabei (Insecta) in relation to its degeneration and regeneration. Protoplasma 247:91-101.

Rost-Roszkowska MM, Vilimova J, Sosinka A, Skudlik J, Franzetti E, 2012. The role of autophagy in the midgut epithelium of Eubranchipus grubii (Crustacea, Branchiopoda, Anostraca). Arthropod Struct. Dev. 41:271-279.

Szymańska B, 1995. Encystment in the tardigrade Dactylobiotus dispar (Murray, 1907) (Tardigrada: Eutardigrada). Part 1: Observation of leaving animals and structure of cyst. Zool. Pol. 40:91-102.

Tettamanti G, Grimaldi A, Pennacchio F, de Eguileor M, 2007. Lepidopteran larval midgut during prepupal instar: digestion or self-digestion? Autophagy 3:630-631.

von Bartheld CS, Altick AL, 2011. Multivesicular bodies in neurons: distribution, protein content, and trafficking functions. Prog. Neurobiol. 93:313-340.

Wełnicz W, Grohme MA, Kaczmarek Ł, Schill RO, Frohme M, 2011. Anhydrobiosis in tardigrades - the last decade. J. Insect Physiol. 57:577-583.

Węglarska B, 1957. On the encystation in Tardigrada. First part. Zool. Pol. 8:315-325.

Wilczek G, 2005. Apoptosis and biochemical biomarkers of stress in spiders from industrially polluted areas exposed to high temperature and dimethoate. Comp. Biochem. Physiol. Part C 141:194-206.

Wright JC, 2001. Cryptobiosis 300 years on from van Leuwenhoek. What have we learned about tardigrades? Zool. Anz. 240:563-582.

Ząbczyk I, 2000. Ultrastructural studies on the midgut of Dactylobiotus dispar (Murray, 1907) (Macrobiotidae, Eutardigrada). Acta Biol. Cracov. Ser. Zool. 42:9-16. 